\title{
Biological effects in Pseudomonas species by the non-thermal atmospheric pressure plasma conditions
}

\author{
Pandu Merum ${ }^{1, a}$, Yuchuan Chu ${ }^{1, b}$, Feng Shi ${ }^{1, \mathrm{c}}$ and Yong Cao ${ }^{1, \mathrm{~d},{ }^{*}}$ \\ ${ }^{1}$ School of mechanical engineering and automation, Harbin institute of technology Shenzhen \\ graduate school, P.R. China \\ apandumerum@yahoo.com, bychuan.chu@hit.edu.cn, cshi.feng@hit.edu.cn, dyongc@hit.edu.cn
}

\begin{abstract}
Keywords: Atmospheric pressure plasma, Scanning electron microscope (SEM), biological changes, Pseudomonas putida.
\end{abstract}

Abstract. Atmospheric pressure plasma is a great technique in plasma science, which was implemented in our research. To study the biological changes in two pseudomonas strains in terms; type of plasma, exposure time and power discharge in the plasma. Scanning electron microscope (SEM) was used to determine the biological changes in two pseudomonas bacterial strains before and after plasma treatment with different time periods, and also recorded the biodegradation activity of two pseudomonas based on the survival bacterial growth rates from the untreated and plasma treated samples. Our results indicated that neutral gas and the atmospheric plasma radiation play a vitol role in the biological changes and also deactivate the bacterial cells such as Pseudomonas putida; Pseudomonas fluorescens. Experimental results proved that, atmospheric argon plasma most effective on pseudomonas bacterial samples and alter the biodegradation activities.

\section{Introduction}

In recent years, many researchers have been developing several new plasma techniques in plasma technology, which are broadly using in various industrial uses [1-11]. An Atmospheric pressure argon plasma is one of the non-thermal plasma, which is created by electric discharges [12]. Generally, interaction mechanisms of non-thermal atmospheric plasma with bacterial cells such as Pseudomonas putida; Pseudomonas fluorescens, and other living cells still not clearly understood, because of plasma complexity and biological in natural properties [13]. Non-thermal atmospheric plasma has a strong ability to disinfect the bacteria in the environments and it alters the metabolism activity in bacteria [14]. Very few researchers reported on the structural effects of atmospheric argon plasmas on bacterial cells $[15,16]$. With this information, to better understand the effects of non-thermal argon plasma on bacterial cells. We investigate the effects of atmospheric plasma on two pseudomonas bacterial strains with various time points of plasma irradiation doses. In addition, we used Scanning electron microscope and emulsification to determine the abnormal changes and growth rates in hydrocarbon oils from untreated and treated bacterial samples. This plasma technique could be potential technique, easy way to handle for deactivate and create mutations in bacterial species and plasma causes slightly increasing the degradation activities in treated pseudomonas cells.

\section{Materials and Methods}

Bacterial strains and Maintenance: We used two Pseudomonas putida and Pseudomonas fluorescens strains as an experimental bacterial strains brought from China General Microbiological Culture Collection Center (CGMCC). A Fresh stock culture of two pseudomonas strains were preserved at $-80\left[{ }^{\circ} \mathrm{C}\right]$ and then streaked on LB agar plates and plates were incubated at $30^{\circ} \mathrm{C}$ for overnight. After incubation, separately rise the fresh $10[\mathrm{ml}]$ of LB broth in a $50 \mathrm{ml}$ falcon tube with isolated colonies. The falcon tubes were incubated at $30\left[{ }^{\circ} \mathrm{C}\right]$, at $180[\mathrm{rpm}]$ for 12 hours. Then, harvested the both bacterial cells after incubation. $1 \mathrm{ml}$ of both bacterial cells were used for centrifuged (5min, 10,000[g]) and discorded the supernatant. Then pellets were rinsed thrice with PBS solution and water, resuspended in LB broth until bacterial growth rate reach to 0.6 Optical density. Then 
aliquots of both bacterial samples, where chemically fixed in the $4 \%$ concentration of formaldehyde and glutaraldehyde for $30 \mathrm{~min}$. Later, two bacterial samples were then centrifuged (5000[g rpm]), supernatant was removed, and pellet resuspended in $1 \mathrm{ml}$ of PBS solution for thrice and then three times rinsed with double distilled water. For the sequential dehydrating steps through the organic solvent (Isopropanol) concentrations $(30,50,60,70,80,90,100,100 \%$ [Vol/Vol]) and transferred to plasma equipment device.

Plasma device, parameters and conditions: APDBD plasma generating electrode protected with quartz tube and used for non-thermal atmospheric pressure dielectric barrier discharge (DBD) plasma generated in a normal laboratory conditions. The device was designed at the laboratory of Harbin institute of technology, Shenzhen graduate School, SHENZHEN, china. The APDBD device was set at 6.8-7.0 [W] and $10[\mathrm{KHz}]$ plasma frequency used $(51 / \mathrm{min})$ for the experiment, bacterial cells were directly exposed to plasma. The distance between bacteria sample and electrode is $4 \mathrm{~cm}$, depends on the plasma, irradiation time, and voltage. Argon gas was used for this experiment, and the argon plasma was created at atmospheric pressure.

Microscope analysis: $1[\mathrm{ml}]$ of each pseudomonas bacterial culture was separated from the overnight culture under laminar hood. Pseudomonas samples were collected at the late growth phase of bacteria. Bacterial samples were prepared further for critical point drying. Twenty minutes after the critical point, the pressure was released gradually, resulting in a dry sample surrounded by $\mathrm{CO}_{2}$ at ambient pressure and temperature. Dry samples were mounted on aluminum stubs $(15[\mathrm{~mm}])$ using double side adhesive carbon tape. The both pseudomonas cells were imaged in a Scanning electron microscope (HITACHI S-4700) and SEM equipped with a cryo transfer system. Images were recorded in a format of $640 \times 480$ pixels.

Deactivation by plasma: For the deactivation test, both pseudomonas cells were suspended in $0.9 \%$ phosphate buffered saline. Later, samples dry at room temperature for dehydration until one hour. After dehydration, each pseudomonas samples were placed in front of nozzle in the way of plasma and then exposed to the various plasma for $0,5,10,15,20,25$ and 30 seconds. After plasma treatment, the irradiated each sample of both pseudomonas cells were transferred separately into a $1 \mathrm{ml}$ of $0.9 \%$ saline, and shaken for $1 \mathrm{~min}$. Plasma treated pseudomonas cells were spread over on LB plate. The number of colonies was counted (Table 1) from untreated and treated samples after 24 hours of incubation at $30\left[{ }^{\circ} \mathrm{C}\right]$.

\begin{tabular}{|l|l|l|l|l|l|l|l|}
\hline $\begin{array}{l}\text { Name of the } \\
\text { microbial } \\
\text { species }\end{array}$ & $\begin{array}{l}0 \\
\text { seconds }\end{array}$ & $\begin{array}{l}5 \\
\text { seconds }\end{array}$ & $\begin{array}{l}10 \\
\text { seconds }\end{array}$ & $\begin{array}{l}15 \\
\text { seconds }\end{array}$ & $\begin{array}{l}20 \\
\text { seconds }\end{array}$ & $\begin{array}{l}25 \\
\text { seconds }\end{array}$ & $\begin{array}{l}30 \\
\text { seconds }\end{array}$ \\
\hline $\begin{array}{c}\text { Pseudomonas } \\
\text { putida }\end{array}$ & 541 & 426 & 328 & 239 & 142 & 171 & 229 \\
\hline $\begin{array}{c}\text { Pseudomonas } \\
\text { fluorescens }\end{array}$ & 520 & 431 & 345 & 258 & 136 & 198 & 245 \\
\hline
\end{tabular}

Table 1: Number of colonies (CFU) from various plasma treated periods of two pseudomonas (Pseudomonas putida and Pseudomonas fluorescens) bacterial species

Characterization of degradation activity: A single colony was collected from of both pseudomonas bacterial strains plates and then inoculated separately into $5 \mathrm{ml}$ of fresh modified LB broth and incubated at $30\left[{ }^{\circ} \mathrm{C}\right]$ for overnight [17]. $1 \mathrm{ml}$ of overnight bacterial culture from both pseudomonas bacterial samples were transferred individually into fresh $5[\mathrm{ml}]$ of LB broth with $500 \mu 1$ of petrol and diesel oils separately. They were incubated for $30\left[{ }^{\circ} \mathrm{C}\right]$ at $180[\mathrm{rpm}]$ overnight. Also maintained another set of control strains for all the experiments. All experiments were done in duplicate. The level of hydrocarbon degradation was determined by using emulsification activity. 


\section{Results and Discussion}

Structural changes in pseudomonas species by the DBD plasma: To determine the effects of non-thermal atmospheric pressure DBD argon plasma on the two pseudomonas bacterial species (Pseudomonas putida; Pseudomonas fluorescens). Freshly prepared both pseudomonas bacterial were exposes to plasma waves. Plasma waves were applied at high energy with $2.45[\mathrm{~Hz}]$ (frequency) and for a short period of time, due to plasma temperature effect is dominant and inactivated the pseudomonas bacterial cells. Many detectable structural changes or damage on the cell wall changes were observed on the cell wall of treated pseudomonas bacterial species (Fig. 1 and Fig. 2 [a-g]) but not in control cells (Fig. 1a and 2a). These damaged effects were caused by movements of cations and anions of the plasma and structural changes of the bacterial cell membrane, which leads to the emergence of pores. Large membrane pores cause leakage of important intracellular molecules come out of the pseudomonas bacterial cells, which may lead to inactivation and bacterial cell death.

a) Control cells

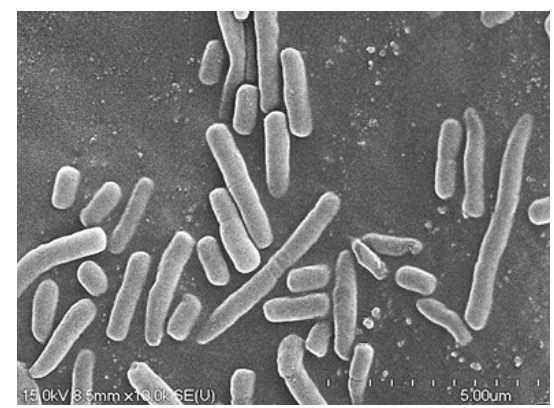

d) 15-seconds exposure

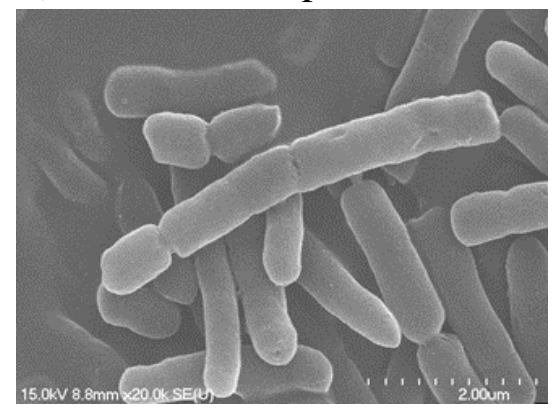

b) 5-seconds exposure

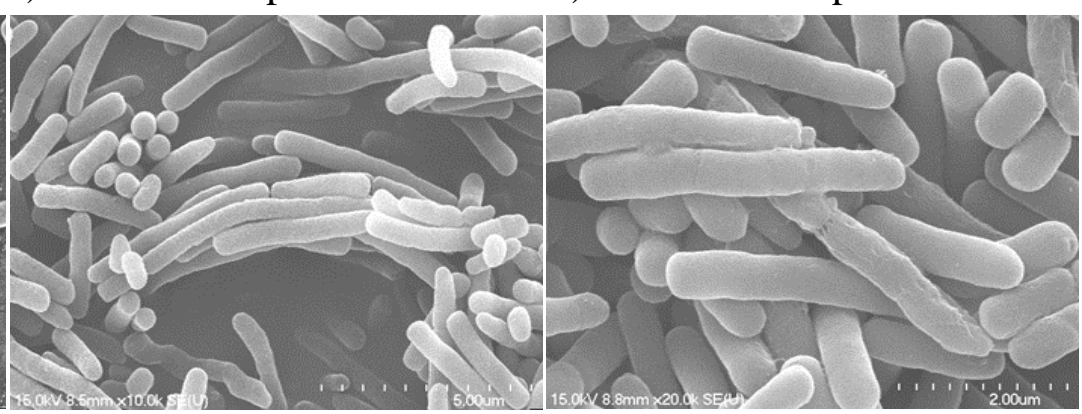

e) 20-seconds exposure

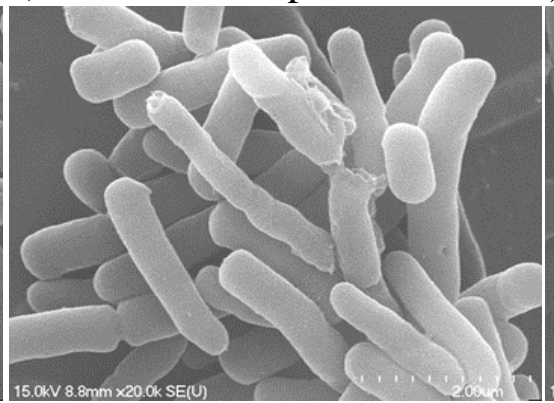

f) 25-seconds exposure

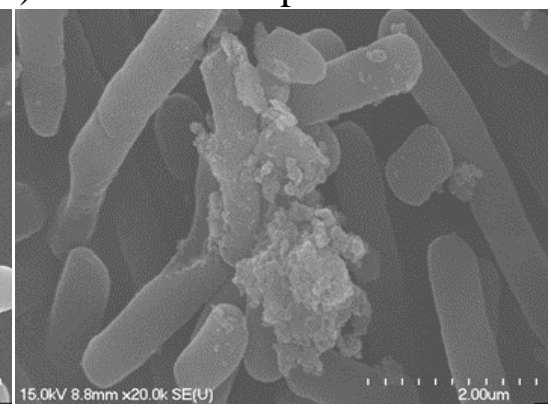

g) 30-seconds exposure

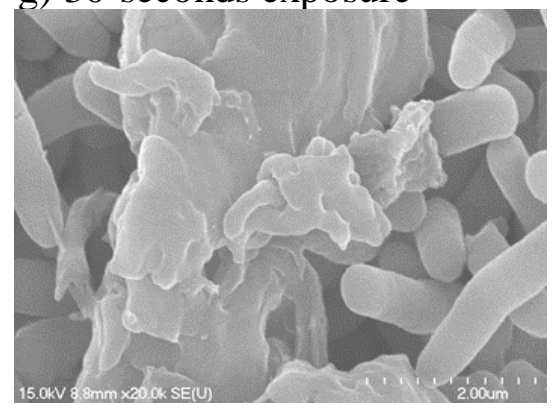

Fig. 1: Scanning electron microscope images of gram-negative bacteria Pseudomonas putida; a) Untreated Pseudomonas putida cells, b-g) 5 seconds of exposure to plasma with Pseudomonas putida cells. 
a) Control cells

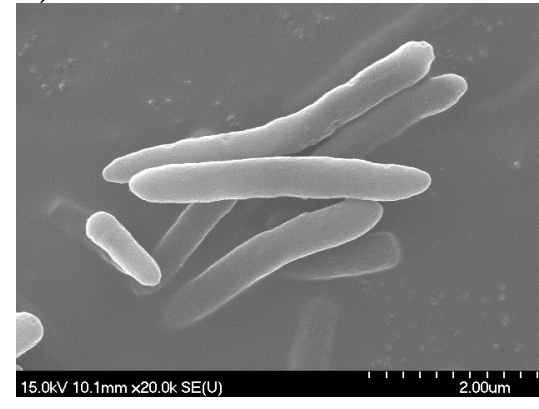

d) 15-seconds exposure b) 5-seconds exposure

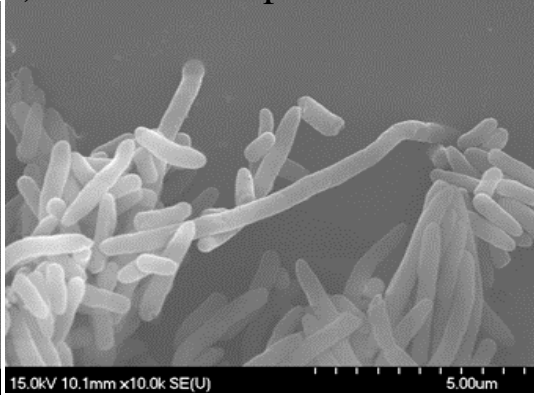

e) 20-seconds exposure c) 10-seconds exposure

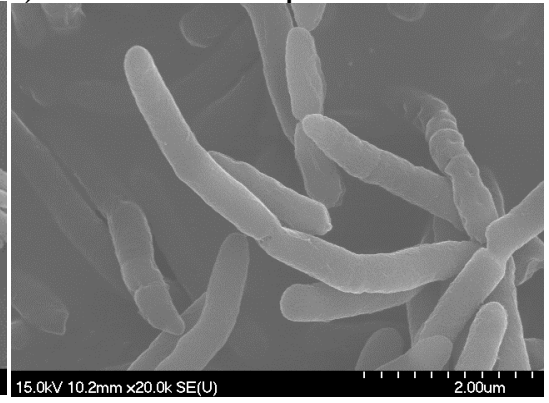

f) 25-seconds exposure

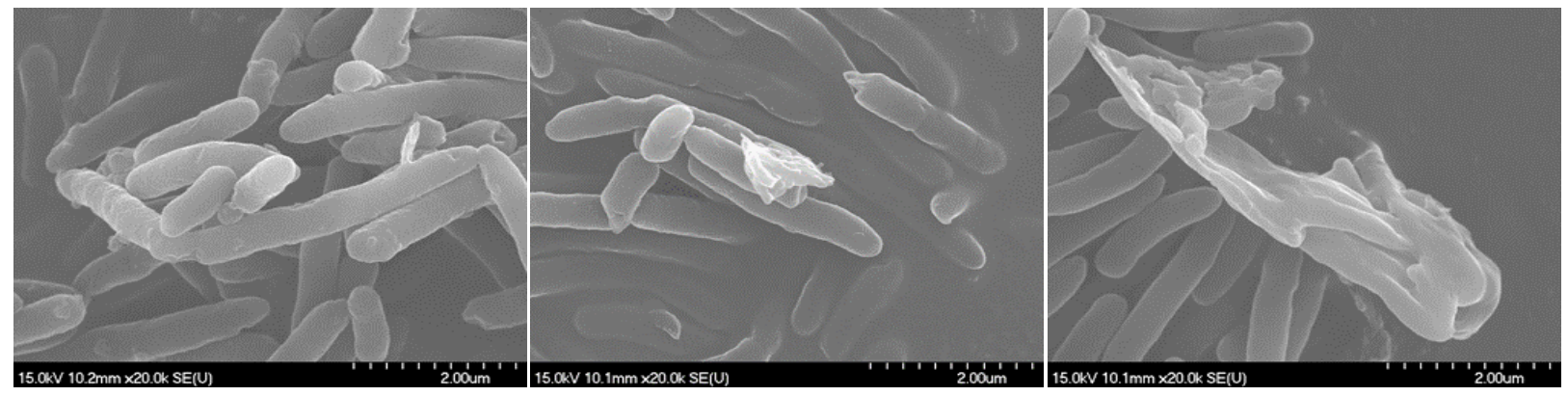

g) 30-seconds exposure

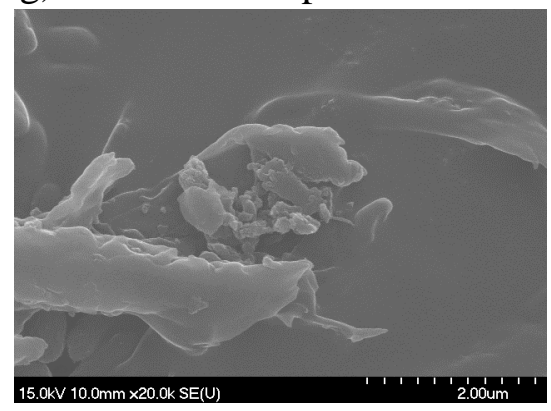

Fig. 2: Scanning electron microscope images of gram- negative bacteria Pseudomonas fluorescens; a)

Untreated Pseudomonas fluorescens cells, b-g) defferent seconds of exposure to plasma with Pseudomonas fluorescens $s$ cells.

Biodegradation activity by the plasma treated Pseudomonas species: Pseudomonas bacterial cells have great features and capable to degrading the hydrocarbon oils from contaminated environments. Hydrocarbon utilization is an important source of carbon and energy for bacterial species. There may be difference in degrading capabilities vary to every microbial species. However, hydrocarbon are necessary for microbial growth at very low-concentrations, when hydrocarbon oils available in high concentrations became toxic to bacterial cells. In such case, to reduce toxic residuals of hydrocarbon oils from the contaminated environments. Microbial cells have the variety of absorption and accumulation mechanisms. Our experimental results also proved that the growth rate of two plasma treated bacteria and untreated bacteria were examined with two different hydrocarbon oils petrol and diesel results were recorded for biodegradation activity (Table $2 \mathrm{a}$ and $2 \mathrm{~b}$ ). The two pseudomonas cells showed maximum growth and higher degradation activity in petrol (3days) compared to diesel. Diesel oil takes more than 15 days to degrade the by the pseudomonas cells. There was progressive increase in the amount of degradation rate under different plasma conditions in petrol compared to diesel. 
a) Petrol degradation activity

\begin{tabular}{|c|c|c|c|c|c|c|c|}
\hline Name of the Microbial species & $\mathbf{0} \mathrm{s}$ & $5 s$ & $10 \mathrm{~s}$ & $15 \mathrm{~s}$ & $20 \mathrm{~s}$ & $25 s$ & $30 \mathrm{~s}$ \\
\hline \multicolumn{8}{|c|}{$1^{\text {st }}$ day Petrol degradation activity } \\
\hline Pseudomonas Putida & ++ & + & - & - & - & - & - \\
\hline Pseudomonas fluorescens & ++ & + & - & - & - & - & - \\
\hline \multicolumn{8}{|c|}{$3^{\text {rd }}$ day petrol degradation activity } \\
\hline Pseudomonas Putida & +++ & +++ & +++ & +++ & +++ & +++ & +++ \\
\hline Pseudomonas fluorescens & +++ & +++ & +++ & +++ & +++ & +++ & +++ \\
\hline
\end{tabular}

b) Diesel degradation activity

\begin{tabular}{|l|l|l|l|l|l|l|l|}
\hline Name of the Microbial species & $\mathbf{0}$ s & $\mathbf{5}$ s & $\mathbf{1 0}$ s & $\mathbf{1 5}$ s & $\mathbf{2 0}$ s & $\mathbf{2 5}$ s & $\mathbf{3 0}$ s \\
\hline $\mathbf{1}^{\text {st }}$ day diesel degradation activity \\
\hline Pseudomonas Putida & ++ & + & - & - & - & - & - \\
\hline Pseudomonas fluorescens & ++ & + & - & - & - & - & - \\
\hline $\mathbf{1 5}^{\text {th }}$ day diesel degradation activity \\
\hline Pseudomonas Putida & ++ & ++ & ++ & ++ & ++ & + & + \\
\hline Pseudomonas fluorescens & ++ & ++ & ++ & ++ & ++ & + & + \\
\hline
\end{tabular}

[- = Nil, + = Low, ++ = Normal, +++ = High $]$

Table2: Biodegradation activity from two pseudomonas bacterial untreated and treated cells.

\section{Conclusions}

This study revealed that, potential of micro-organisms have evolved with various tolerance mechanisms to cope with toxicant pollutants in environments. Some mechanisms helping to bacteria while growing in polluted environments to translocate the toxic residuals of hydrocarbon oils or metals from cytoplasm to vacuole or outside the microbial cells. But it's enough to degrade the hydrocarbon oils with bacterial instinct enzymes activities. Its need to be alter the microbial genomes to produces more effect metabolites to degrade the high concentration of oil residuals from the environments. Recent years, many researchers using plasma technology and proven that efficient technique to date. Further, many researchers in this area can use to inactivate and mutate the bacteria with less time of atmospheric plasma and helps atmospheric plasma to improve the reducing enzymes in plasma treated bacterial species. Better option of polluted environment adopted mutant micro-organisms by plasma that detoxification and stabilizing with low investment expenses and of no damage to environment.

\section{Acknowledgements}

The work described in this paper was supported by a grant from Shenzhen Technology Project (Project No. JCYJ20160226201347750 and GJHZ20160226200952216). The financial support is gratefully acknowledged.

\section{References}

[1] J. Roth, S. Nourgostar and T. Bonds: IEEE Trans. Plasma Sci. Vol. 35(2007), p. 233

[2] J. Park, S. Nam, H. Kwon, A. Mohamed, J. Lee and G. Kim: Int. Endod. J. Vol. 44 (2011), p.170

[3] J. Heinlin, G. Morfill, M. Landthaler, W. Stolz, G. Isbary, J.L. Zimmermann, T. Shimizu and 
S. Karrer: J. Gem. Soc. Dermatol. Vol. 8 (2010), p. 968

[4] G. Lloyd, G. Friedman, S. Jafri, G. Schultz, A. Fridman and K. Harding: Plasma Process. Polym. Vol. 7 (2010), p. 194

[5] C. Jiang, M.T. Chen, C. Schaudinn, A. Gorur, P.T. Vernier, J.W. Costerton, D.E. Jaramillo, P.P. Sedghizadeh and M.A. Gundersen: IEEE Trans. Plasma Sci. Vol. 37 (2009), p. 1190

[6] G. Fridman, G. Friedman, A. Gutsol, A. Shekhter, V. Vasilets and A. Friedman: Plasma Process. Polym. Vol. 5 (2008), p. 503

[7] S. Kalghatgi, G. Fridman, M. Cooper, G. Nagaraj, M. Peddinghaus, M. Balasubramanian, V. Vasilets, A. Gutsol, A. Fridman and G. Friedman: IEEE Trans. Plasma Sci. Vol. 35 (2007), p. 1559

[8] I. Kieft, J. Broers, V. Caubet Hilloutou, D. Slaaf, F. Ramaekers and E. Stoffels: Bioelectromagnetics Vol. 25 (2004), p. 362

[9] E. Stoffels, I. Kieft and R. Sladek: J. Phys. D: Appl. Phys. Vol. 36 (2003), Article ID 2908

[10] G.Y. Park, S.J. Park, M.Y. Choi, I.G. Koo, J.H. Byun, J.W. Hong, J.Y. Sim, G.J. Collins and J.K. Lee: Plasma Sources Sci. Technol. Vol. 21(2012), Article ID 043001

[11] F. Iza, G.J. Kim, S.M. Lee, J.K. Lee, J.L. Walsh, Y.T. Zhang and M.G. Kong: Plasma Process. Polym. Vol. 5 (2008), p. 322

[12] C. Tendero, C. Tixier, P. Tristant, J. Desmaison and P. Leprince: Spectrochim. Acta B Vol. 61 (2006), p. 2

[13] D. Dobrynin, G. Fridman, G. Friedman and A. Fridman: New J. Phys. Vol. 11 (2009), 115020

[14] G. Fridman, A.D. Brooks, M. Balasubramanian, A. Fridman, A. Gutsol, V. Vasilets, H. Ayan and G. Friedman: Plasma Process. Polym. Vol. 4 (2007), p. 370

[15] A. Morris, G. McComns, T. Akan, W. Hynes, M. Laroussi and S. Tolle: Journal of Dental Hygiene Vol. 83(2009), p. 55

[16] M. Mols, H. Mastwijk, M. Nierop Groot and T. Abee: J. Appl. Microbiol. Vol. 115 (2013), p. 689

[17] K. Santhini, J. Myla, S. Sajani and G. Usharani: Botany research international Vol. 2 (2009), p. 248 